\title{
Non-radioactive in-situ hybridisation to honeybee embryos and ovaries ${ }^{1}$
}

\author{
Peter OSBORnE, Peter K. DEARDEN* \\ Laboratory for Development and Evolution, Biochemistry Department, University of Otago, Dunedin, \\ New Zealand
}

Received 5 July 2004 - Revised 23 August 2004 - Accepted 26 August 2004

Published online 16 March 2005

\begin{abstract}
To study the function and expression of genes identified in the honeybee genome sequence, techniques for assaying gene expression need to be developed. We present a robust method for preparing honeybee embryos and ovaries for in-situ hybridisation. This protocol should prove useful for researchers wishing to use the genome sequence to study honeybee biology.
\end{abstract}

Apis mellifera / embryo / ovary / gene expression / in-situ hybridisation

\section{INTRODUCTION}

The release of the honeybee (Apis mellifera L.) genome sequence makes the honeybee an attractive and important system for the study of gene expression during development. In order to perform these analyses, however, techniques for assaying gene expression in the honeybee need to be developed. In-situ hybridisation of whole mount tissues is the standard method for determining both temporal and spatial gene expression patterns in insects (Tautz and Lehmann, 1994; Xu et al., 1994; Schulz et al., 1998; Dearden and Akam, 2000). While in-situ hybridisation protocols exist for specific adult honeybee tissues (for example see Kurshan et al., 2003), none have been published for embryos or ovaries.

The membranes of honeybee eggs pose a particular challenge to in-situ hybridisation and immunohistochemistry of whole mount embryos. The embryo is surrounded, from oviposition, by two membranes, the chorion and vitelline membrane. Both of these membranes have to be removed for efficient staining to occur. From about 50 hours after egg laying (Fleig and Sander, 1986) embryos are firm enough so they may be dissected from the membranes with ease. With earlier embryos, however, this is impossible. We have adapted methods for fixing and removing membranes from Drosophila (Patel, 1994), Zebrafish (Westerfield, 2000) and Spider mites (Dearden et al., 2002) and have produced a technique for removing the membranes from all embryonic stages of honeybees, as well as preparing ovary tissues.

The typical in-situ hybridisation method uses digoxigenin (DIG) labelled RNA probes directed to the transcript of interest (Tautz and Pfeifle, 1989; Tautz and Lehmann, 1994). The DIG hapten is then detected using an anti-DIG antibody conjugated with alkaline phosphatase. This method is fast and sensitive, when compared to radioactive methods (Akam, 1983; Akam and Carlson, 1985), and more robust than current fluorescence based techniques (Hughes et al., 1996; Hughes and Krause, 1998). We have adapted this method for use with whole-mount honeybee embryos. This technique is also amenable to double label in-situ

\footnotetext{
* Corresponding author: peter.dearden@stonebow.otago.ac.nz

${ }^{1}$ Manuscript editor: Klaus Hartfelder
} 
hybridisation using fluorescein or biotin labelled probes (Hauptmann and Gerster, 1996).

\section{MATERIALS AND METHODS}

\subsection{RNA probe preparation}

Digoxigenin (DIG) labelled RNA probes were produced by run off transcription. Plasmid vectors containing clones of interest were linearised with the appropriate restriction endonuclease for $1-3 \mathrm{~h}$, cleaned with a phenol/chloroform extraction and precipitated with sodium acetate and ethanol. The linearised DNA template was resuspended in $11 \mu \mathrm{L}$ of Diethyl-pyrocarbonate (DEPC) treated water and allowed to dissolve. Two $\mu \mathrm{L}$ of $10 \mathrm{x}$ transcription buffer, $2 \mu \mathrm{L}$ of DIG RNA labelling mix (Roche Applied Science), $1 \mu \mathrm{L}$ of $0.1 \mathrm{M}$ Dithiothreitol (DTT), $2 \mu \mathrm{L}$ of RNase Inhibitor (Roche Applied Science), and $2 \mu \mathrm{L}$ of the appropriate RNA polymerase (Roche Applied Science) were added and the reaction incubated at $37{ }^{\circ} \mathrm{C}$ for 2 hours- overnight. DNA template was degraded by adding $1 \mu \mathrm{L}$ of RNase free DNase (Roche Applied Science) for $15 \mathrm{~min}$, and the RNA precipitated with $1 \mu \mathrm{L}$ of $10 \mathrm{M}$ ammonium acetate and $20 \mu \mathrm{L}$ of isopropanol. After centrifugation, the pellet was washed in $70 \%$ ethanol, dried at room temperature, and resuspended in 50-100 $\mu \mathrm{L}$ of Hybridisation buffer $50 \%$ formamide, $4 \mathrm{X}$ Standard Saline Citrate (SSC), 1X Denhardt's solution, $250 \mu \mathrm{g} / \mathrm{mL}$ yeast total RNA, $250 \mu \mathrm{g} / \mathrm{mL}$ boiled salmon sperm or calf thymus DNA, $50 \mu \mathrm{g} / \mathrm{mL}$ heparin (Sigma), $0.1 \%$ Tween 20,5\% dextran sulfate), depending on the size of the pellet. RNA probes were stored at $-20^{\circ} \mathrm{C}$.

Just before use, $2-5 \mu \mathrm{L}$ of probe was placed in a microcentrifuge tube with an equal volume of carbonate buffer $\left(120 \mathrm{mM} \mathrm{Na}_{2} \mathrm{CO}_{3}, 80 \mathrm{mM} \mathrm{NaHCO}_{3}\right.$, $\mathrm{pH} 10.2$ ) and incubated at $60{ }^{\circ} \mathrm{C}$ for $30 \mathrm{~min}$. Six volumes of hybridisation buffer were then added to halt the reaction.

\subsection{Embryo collection and processing}

Embryos were recovered from honeybee brood combs using a damp paintbrush and immediately placed in a fixative solution containing a 1:1 mix of heptane: $4 \%$ formaldehyde in phosphate buffered saline (PBS) in a microcentrifuge tube. Following collection, embryos were shaken overnight on a shaking platform set at a moderate speed. The lower fixative phase was removed with a glass Pasteur pipette and $0.5 \mathrm{ml}$ of methanol, equilibrated to $-20^{\circ} \mathrm{C}$, was added to the embryos and the mixture shaken vigorously for a few minutes. The heptane/ methanol mixture was removed and the fixed embryos washed 3 times in fresh methanol. Embryos can be stored at this point at $-20{ }^{\circ} \mathrm{C}$ in methanol.

Embryos were equilibrated to room temperature, and then as much of the methanol as possible removed and replaced with PTw (PBS $+0.1 \%$ Tween 20). Embryos were allowed to settle and transferred into a thin walled glass test tube with at least $2 \mathrm{~mL}$ of PTw. The embryos were then sonicated in a sonic cleaning bath (Soniclean, Transtek systems) for 10-60 s (see results) to break the chorion. After sonication, the embryos were allowed to settle, transferred back into a microcentrifuge tube, and the PTw replaced with $50-100 \mu \mathrm{L}$ of $200 \mu \mathrm{g} / \mathrm{mL}$ Pronase (Roche Applied Science) in PTw. The vitelline membrane was digested with the Pronase for 810 min and the embryos rinsed twice in PTw.

After transferring the embryos to a small plastic tissue culture dish containing PTw, the remains of the chorion and vitelline membrane were peeled from the embryo using fine forceps (Dumont 55 Biologie).

Peeled embryos were collected in PTw. If necessary, embryos can be dehydrated in methanol and stored at $-20^{\circ} \mathrm{C}$ at this point. Embryos were digested for 5-10 min in PTw $+20 \mu \mathrm{g} / \mathrm{mL}$ Proteinase $\mathrm{K}$ (Sigma), rinsed in PTw and postfixed in PTw $+4 \%$ formaldehyde for at least $15 \mathrm{~min}$. Embryos were then rinsed six times in PTw and transferred to $1 \mathrm{~mL}$ of Hybridisation buffer and prehybridised at $52{ }^{\circ} \mathrm{C}$ for a minimum of $2 \mathrm{~h}$.

\subsection{Ovary dissection and processing}

Queen bees were etherised and their abdomens removed. The abdomens were cut open with scissors from the dorsal surface and the paired ovaries removed into ice cold PBS. The dissected ovaries were rinsed in ice cold PBS and transferred into a 1:1 mixture of Fixation buffer (4\% Formaldehyde, $20 \mathrm{mM} \mathrm{KH}_{2} \mathrm{PO}_{4} / \mathrm{K}_{2} \mathrm{HPO}_{4} \mathrm{pH} 6.8,90 \mathrm{mM} \mathrm{KCl}$, $30 \mathrm{mM} \mathrm{NaCl}, 4 \mathrm{mM} \mathrm{MgCl}_{2}$ ) (White, 1998) and heptane (heptane appears to improve penetration through the membrane surrounding each ovariole). Ovaries were fixed overnight with shaking in this mixture, and then washed three times in PBS. Ovaries can be dehydrated through a methanol series and stored in methanol at $-20^{\circ} \mathrm{C}$.

Individual ovariole strands were dissected from the ovary mass in PBS using fine forceps. Isolated ovarioles were transferred to a microcentrifuge tube containing PTw. Ovarioles were digested with $20 \mu \mathrm{g} / \mathrm{mL}$ Proteinase $\mathrm{K}$ for $15 \mathrm{~min}$ and then rinsed in PTw. Ovarioles were postfixed for 15 min in PTw $+4 \%$ formaldehyde. After rinsing six times in PTw, ovarioles were transferred to $1 \mathrm{~mL}$ of hybridisation buffer and prehybridised at $52{ }^{\circ} \mathrm{C}$ for at least $2 \mathrm{~h}$. 


\subsection{In-situ hybridisation}

The prehybridisation solution was removed from the embryos or ovarioles and replaced with digested probe in hybridisation buffer. Tissue was then incubated overnight at $52{ }^{\circ} \mathrm{C}$. The tissue was washed in Wash buffer $(50 \%$ formamide, $2 \mathrm{X}$ SSC, $0.1 \%$ Tween 20) 10 times in $2 \mathrm{~h}$, and finally overnight at $52{ }^{\circ} \mathrm{C}$.

Tissue was then rinsed three times in PTw and blocked for $30 \mathrm{~min}$ in PBTw (PTw $+0.1 \%$ bovine serum albumin (Gibco-BRL)). The DIG hapten is detected with a 1:500 dilution of anti-DIG- alkaline phosphatase antibodies (Roche Applied Science) in PBTw for $90 \mathrm{~min}$ at room temperature. The tissue was then washed in PTw 6 times over $2 \mathrm{~h}$ at room temperature and then equilibrated with two five minute washes in AP buffer (100 mM Tris $\mathrm{pH} 9.5$, $100 \mathrm{mM} \mathrm{NaCl}, 50 \mathrm{mM} \mathrm{MgCl}_{2}, 0.1 \%$ Tween 20). The alkaline phosphatase enzyme was detected with $4.5 \mu \mathrm{l}$ Nitroblue tetrazolium chloride $(75 \mathrm{mg} / \mathrm{mL}$ in Dimethylformamide (DMF), Roche Applied Science) and 3.5 $\mu \mathrm{L} 5$-Bromo-4 chloro-3-indolyl-phosphate $(50 \mathrm{mg} / \mathrm{mL}$ in DMF, Roche Applied Science). Tissue was deliberately over-stained and then destained in methanol. Tissue was stored in methanol at $-20{ }^{\circ} \mathrm{C}$ or rehydrated in PTw, cleared in $50 \%$ glycerol, and mounted in $70 \%$ glycerol. Tissue can also be stored in $70 \%$ glycerol at $4{ }^{\circ} \mathrm{C}$.

\subsection{Imaging}

Embryos and ovarioles were imaged with an Olympus BX51 microscope using bright field optics. Images were captured using a Magnafire (Optronics) digital camera and Magnafire software. Images were processed and scale bars added using Adobe Photoshop.

\section{RESULTS AND DISCUSSION}

In this paper we present a method for reliably preparing honeybee embryos and ovaries for in-situ hybridisation (Fig. 1). This technique has proven a robust method for assaying gene expression using both cDNA and gDNA (intron containing) derived probes. For genomic DNA probes, at least 300 bases of coding sequence seem necessary for clean signal. This technique should be of utility to researchers wishing to quickly determine the expression of a putative exon from the genome sequence, and may be useful for high throughput screening of putative exons for embryonic expression using an automated in-situ hybridisation system (Plickert et al., 1997).
DIG labelled probes are produced by runoff transcription and resuspended in hybridisation buffer at concentrations of about 100 $500 \mathrm{ng} / \mu \mathrm{L}$. Probes are digested for $30 \mathrm{~min}$ at $60{ }^{\circ} \mathrm{C}$ in carbonate buffer to aid tissue penetration, and applied to the tissue at a concentration of approximately $4 \mathrm{ng} / \mu \mathrm{L}$. We have not found the concentration or length of the probes (as long as it is over 300 base pairs) to be critical in producing good staining. We have not detected any loss of activity from probes over a year old.

The key to our method is the fixation; embryos must be fixed sufficiently, through the chorion and vitelline membrane, to survive the sonication and peeling steps. We have tried fixation times of 1 hour, 4 hours and overnight, and find the overnight ( $>12 \mathrm{~h}$ ) fixation to be necessary for the embryos to be firm enough to peel. Embryos fixed for 1 or $4 \mathrm{~h}$ are too delicate to sonicate or peel. It is possible to remove the chorion with a brief wash (3 min or less) in $4 \%$ Sodium hypochlorite, and then fix the embryos, but this hardens the vitelline membrane such that it is difficult to remove. The long fixation time in this protocol, however, precludes easy antibody staining after in-situ hybridisation.

After fixation, the embryos are stored in methanol at $-20{ }^{\circ} \mathrm{C}$. Fixed ovaries can also be stored in methanol for considerable periods. We have obtained excellent hybridisation signals from embryos and ovaries stored in methanol for 6 months.

After rehydration, the embryos were sonicated in a sonic cleaning bath. This makes holes in the chorion (and to a lesser extent, the vitelline membrane), which allows the subsequent Pronase step to weaken the vitelline membrane. We sonicate by swirling the embryos such that they are off the bottom of the tube, and then place the tube into the bath for a few seconds. This is repeated until the solution goes slightly cloudy, indicating the beginning of damage to the embryos themselves. Over-sonication results in complete destruction of the embryos. Sonicated embryos are then ready for digestion with Pronase, and finally dissection.

The dissection step is also critical to the procedure; each embryo must have both membranes removed for any staining to be visible. In many cases the damage to both membranes 

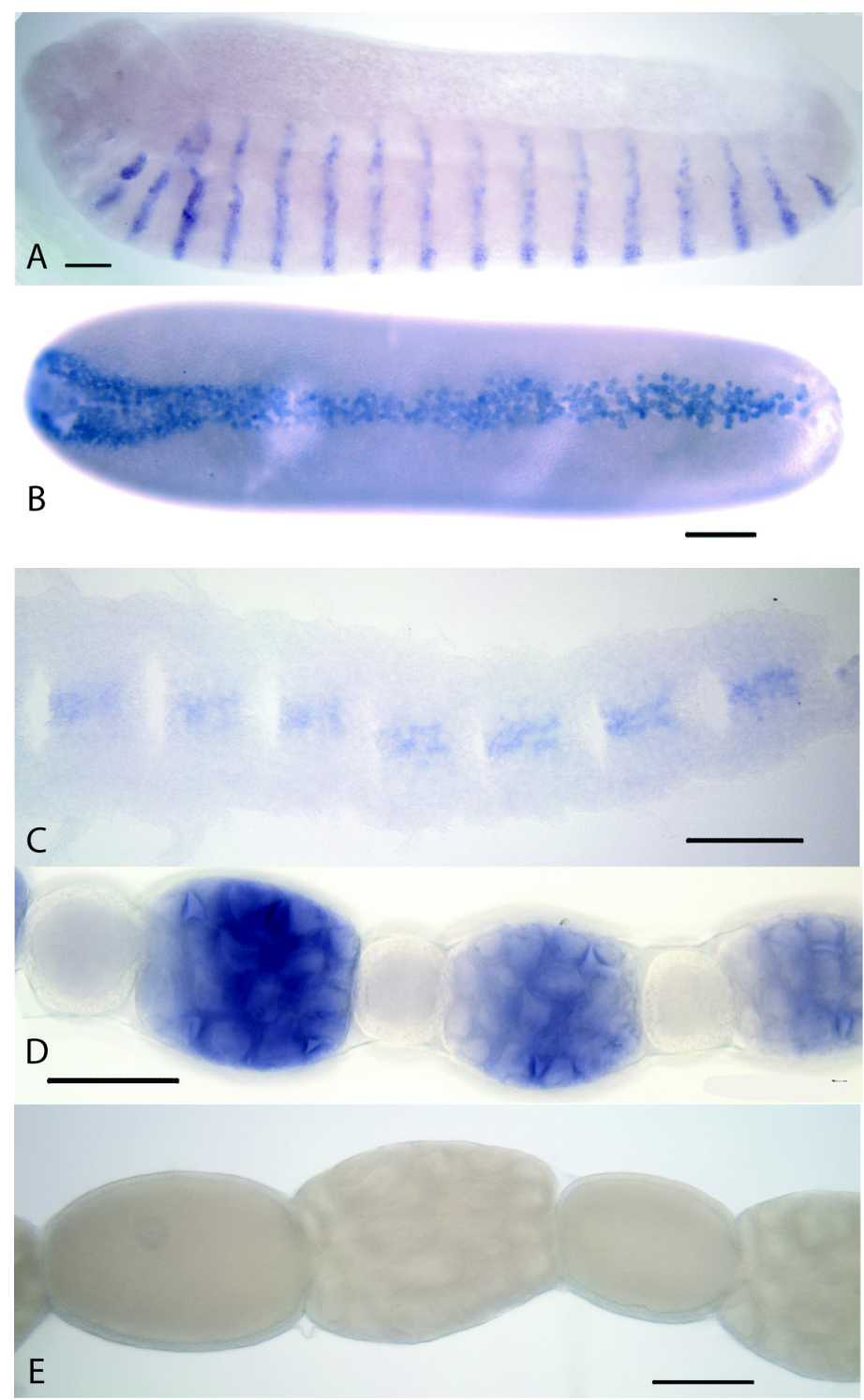

Figure 1. Honeybee embryos (A, B and C) and ovaries (D and E) hybridised with a selection of DIG labelled RNA probes as described. Scale bars represent $100 \mu \mathrm{m}$. (A) Late stage embryo hybridised with a probe against $e 30$, a homologue of the Drosophila engrailed gene (Fleig, 1990), derived from a genomic clone. Drosophila engrailed is expressed in the posterior of each segment and acts to define and maintain the parasegment boundary (Akam, 1987). Similar to Drosophila engrailed, e30 is expressed in a stripe in the posterior of each segment from the gnathum posterior. Faint domains of expression are also present in the head. (B) Early stage embryo hybridised with a probe for a homologue of the Hox 3 gene, derived from a genomic clone. Hox 3 is expressed in the dorsal stripe, a pattern consistent with the function of zen in Drosophila (Rushlow et al., 1987), and Hox 3 in Tribolium (Falciani et al., 1996) and Schistocerca (Dearden et al., 2000), where it regulates the formation of the extraembryonic membranes. (C) Dissected late stage central nervous system hybridised with a probe against a homologue of the slit gene derived from a cDNA clone (Whitfield et al., 2002). Slit is a conserved regulator of axon targeting, expressed in the midline glia in Drosophila (Battye et al., 1999). (D) Part of an ovariole hybridised with a probe for a homologue of the vasa gene, a conserved regulator of germ cell fate (Raz, 2000; Chang et al., 2002; Dearden et al., 2003), derived from a genomic clone. (E) Sense control for D. 
is such that they are easily removed, in other cases careful peeling is necessary. A good dissecting microscope and sharp forceps greatly improves success.

After digestion with Proteinase K, the fixation step serves to stabilise the embryos. It is important for good signal development that the fixative is thoroughly washed away before prehybridisation.

The hybridisation and washing steps have been designed to allow very little disturbance of the embryos themselves. It is sufficient to remove $70-80 \%$ of the previous solution at each step, reducing the disturbance to delicate tissues throughout the protocol. After the hybridisation step, it is not necessary to remove the probe before adding the first wash buffer; thereby ensuring no embryos are lost.

The final staining step can be left to overstain. Staining times can range from several minutes to 3-4 h, depending on levels of expression and concentration of the probe. Using probes at the concentrations described usually ensures that staining overnight is not necessary. Dehydrating the tissue in methanol after staining removes the pink background, leaving only an intense blue colour. This destaining step allows us to stain the embryos until specific staining is a deep purple colour and unstained regions are pink. Methanol treatment will then leave specific staining blue and the unstained embryos clear. The de-staining step can be manipulated by monitoring the methanol wash with a dissecting microscope and rehydrating the embryos when an appropriate level of staining is achieved. We usually allow the reaction to go to completion (5-10 m), washing the tissue several times in fresh methanol.

This technique is a robust method for determining the expression of gDNA or cDNA fragments in both honeybee ovaries and embryos. The technique relies on a novel method for weakening both the chorion and vitelline membrane such that they can be dissected easily away. This technique should prove useful to researchers wishing to exploit the genome data for an understanding of gene regulation and honeybee embryology.

\section{ACKNOWLEDGEMENTS}

We thank Elaine Emmerson for technical support and Euan McNaughton for the production of the slit antisense RNA probe. This project was supported by a University of Otago Research Grant.

Résumé - Hybridation in-situ non radioactive pour embryons et ovaires d'abeilles domestiques. L'achèvement du séquençage du génome de l'Abeille domestique (Apis mellifera L.) fournit aux chercheurs l'occasion d'étudier l'expression et la régulation des gènes. Nous présentons ici des modifications à la technique standard d'hybridation in-situ qui faciliteront l'étude des profils d'expression génétique chez les ovaires et les embryons des abeilles domestiques. En combinant un certain nombre de techniques pour l'hybridation in-situ d'un certain nombre d'embryons d'abeilles et en trouvant une méthode pour digérer les membranes d'embryons, nous avons pu mettre au point une méthode solide pour l'hybridation in-situ. Nous espérons que cette technique sera utile aux chercheurs qui étudient l'embryogenèse de l'Abeille domestique.

\section{Apis mellifera / embryon / ovaire / expression génétique / hybridation in-situ}

Zusamennfassung - Nicht-radioaktive in-situHybridisieriung an Embryonen und Ovarien der Honigbiene. Mit der nun nahezu kompletten Sequenzierung des Genoms der Honigbiene stehen der Forschung eine Reihe von Möglichkeiten offen, um die Expression bestimmter Gene und deren Regulation $\mathrm{zu}$ untersuchen. In der vorliegenden Arbeit beschreiben wir einige Modifikationen $\mathrm{zu}$ Standardverfahren der in-situ Hybridisierung, die die Visualisierung der Expression bestimmter Gene im Ovar der Honigbienen und in Embryonen erleichtern. Durch die Kombination verschiedener Protokolle zur in-situ Hybridisierung an tierischen Embryonen und der Entwicklung eines Verfahrens zum Abverdau des Chorions und der Entfernung der Eimembranen der Bienenembryonen gelang es uns, ein robustes Verfahren für in-situ Hybridisierungen zu entwickeln. Wir hoffen, dass dieses Verfahren sich in vielen Studien zur Embryogenese der Honigbiene als nützlich erweisen wird.

Apis mellifera / Ovar / Embryo / Genexpression / in-situ Hybridisierung

\section{REFERENCES}

Akam M.E. (1983) The location of Ultrabithorax transcripts in Drosophila tissue sections, EMBO J. 2, 2075-2084.

Akam M.E., Carlson J.R. (1985) The detection of Jonah gene transcripts in Drosophila by in situ hybridization, EMBO J. 4, 155-161. 
Akam M.E. (1987) The molecular basis for metameric pattern in the Drosophila embryo, Development $101,1-22$.

Battye R., Stevens A., Jacobs J.R. (1999) Axon repulsion from the midline of the Drosophila CNS requires slit function, Development 126, 24752481.

Chang C., Dearden P., Akam M. (2002) Germ line development in the grasshopper Schistocerca gregaria, Dev. Biol. 252, 100-118.

Dearden P., Grbic M., Falciani F., Akam M. (2000) Maternal Expression and early zygotic expression of the Hox3/zen gene in Schistocerca, Evol. Dev. 2, 261-270.

Dearden P.K., Akam M.E. (2000) A Role for Fringe in Segment morphogenesis but not segment formation in the grasshopper, Schistocerca gregaria, Dev. Genes Evol. 210, 329-336.

Dearden P., Donly C., Grbic M. (2002) Expression of pair-rule gene homologues in a chelicerate: early patterning of the Two-Spotted Spider Mite Tetranychus urticae, Development 129, 5461-5472.

Dearden P.K., Grbic M., Donly C. (2003) Vasa expression and Germ Cell Specification in the Spider mite Tetranychus urticae, Dev. Genes Evol. 212, 599-603.

Falciani F., Hausdorf B., Schröder R., Akam M., Tautz D., Denell R., Brown S. (1996) Class 3 Hox genes in insects and the origin of zen, Proc. Natl. Acad. Sci. (USA) 93, 8479-8484.

Fleig R. (1990) Engrailed expression and body segmentation in the Honeybee Apis mellifera, Roux's Archiv. Dev. Biol. 198, 467-473.

Fleig R., Sander K. (1986) Embryogenesis of the honeybee Apis mellifera L. (Hymenoptera: Apidae): an SEM study, Int. J. Insect. Morphol. 15, 449-462.

Hauptmann G., Gerster T. (1996) Multicolour wholemount in situ hybridization to Drosophila embryos, Dev. Genes Evol. 206, 292-295.

Hughes S., Krause H.M. (1998) Single and Double FISH protocols for Drosophila, in: Paddock S. (Ed.), Protocols in Confocal microscopy, Humana press.

Hughes S.C., Saulier-Le Drean B., Livne-Bar I., Krause H.M. (1996) Fluorescence in situ hybridization in whole-mount Drosophila embryos, Biotechniques 20, 748-750.

Kurshan P.T., Hamilton I.S., Mustard J.A., Mercer A.R. (2003) Developmental changes in expression patterns of two dopamine receptor genes in mushroom bodies of the honey bee, Apis mellifera, J. Comp. Neurol. 466, 91-103.

Patel N.H. (1994) Imaging neuronal subsets and other cell types in whole-mount Drosophila embryos and larvae using antibody probes, in: Goldstein L.S.B., Fyrberg E.A. (Eds.), Drosophila melanogaster: Practical uses in Cell and Molecular biology, Academic Press, London, pp. 446-485.

Plickert G., Gajewski M., Gehrke G., Gausepohl H., Schlossherr J., Ibrahim H. (1997) Automated in situ detection (AISD) of biomolecules, Dev. Genes Evol. 207, 362-367.

Raz E. (2000) The function and regulation of vasa-like genes in germ-cell development, Genome Biol. 1, 1017.

Rushlow C., Frasch M., Doyle H., Levine M. (1987) Maternal regulation of zerknullt: a homoeobox gene controlling differentiation of dorsal tissues in Drosophila, Nature 330, 583-586.

Schulz C., Schroder R., Hausdorf B., Wolff C., Tautz D. (1998) A caudal homologue in the short germ band beetle Tribolium shows similarities to both the Drosophila and the vertebrate caudal expression patterns, Dev. Genes Evol. 208, 283-289.

Tautz D., Lehmann R. (1994) In situ hybridization to RNA, Biotechniques 44, 575-598.

Tautz D., Pfeifle C. (1989) A non-radioactive in situ hybridisation method for the localisation of specific RNAs in Drosophila embryos reveals translational control of the segmentation gene hunchback, Chromosoma 98, 81-85.

Westerfield M. (2000) The zebrafish book. A guide for the laboratory use of zebrafish (Danio rerio), Univ. of Oregon Press, Eugene.

White R.A. (1998) Immunolabelling of Drosophila, in: Roberts D.B. (Ed.), Drosophila: a practical approach, Oxford University Press, Oxford, pp. 215-240.

Whitfield C.W., Band M.R., Bonaldo M.F., Kumar C.G., Liu L., Pardinas J.R., Robertson H.M., Soares M.B., Robinson G.E. (2002) Annotated expressed sequence tags and cDNA microarrays for studies of brain and behavior in the honey bee, Genome Res. 12, 555-566.

Xu X., Xu P.X., Suzuki Y. (1994) A maternal homeobox gene, Bombyx caudal, forms both mRNA and protein concentration gradients spanning anteroposterior axis during gastrulation, Development 120, 277-285. 